Pak. j. sci. ind. res. Ser. B: biol. sci. 201255 (2) 59-64

\title{
Effect of Wheat Residue Incorporation Along with N Starter Dose on Rice Yield and Soil Health Under Saline Sodic Soil
}

\author{
Syed Ishtiaq Hyder*, Muhammad Arshadullah and Arshad Ali \\ Land Resources Research Institute, National Agricultural Research Centre, \\ Park Road, Islamabad-45500, Pakistan \\ (received March 29, 2011; revised November 11, 2011; accepted November 28, 2011)
}

\begin{abstract}
A field experiment was conducted to determine the effect of crop residue incorporation@ 5 tons wheat straw/ha along with $\mathrm{N}$ starter dose $(0,30 \mathrm{~kg} \mathrm{~N} / \mathrm{ha}, 60 \mathrm{~kg} \mathrm{~N} / \mathrm{ha}$ and $90 \mathrm{~kg} \mathrm{~N} / \mathrm{ha}$ ) on rice (super basmati) production and soil health under saline sodic soils $(\mathrm{ECe}=5.32 \mathrm{dS} / \mathrm{m}, \mathrm{pH}=8.52$ and $\mathrm{SAR}=18.38$ ) during 2009. Treatments were arranged using randomized complete block design (RCBD) with three replications. The crop was harvested at maturity, data on tillering, plant height, spike length, number of grains/ spike, 1000-grain weight, straw and paddy yields were recorded. $\mathrm{Na}, \mathrm{K}, \mathrm{Ca}$ and $\mathrm{N}$ concentration in grain and straw were estimated using atomic absorption spectroscopy. Tillering, number of grains/spike, 1000 -grain weight and paddy yield significantly $(\mathrm{P} \leq 0.05)$ increased by different levels of doses. Maximum plant height $(135.66 \mathrm{~cm})$ and numbers of grains/spike $(140.33)$, spike length $(24.66 \mathrm{~cm})$, number of tillers/plant (40.33) and 1000-grain weight (23 g) were recorded at the application of 5 tons wheat straw/ha along with $90 \mathrm{~kg} \mathrm{~N} / \mathrm{ha}$. Grain yield was the maximum (3.32 t/ha) at the application of 5 tons wheat straw /ha along with $90 \mathrm{~kg} \mathrm{~N} / \mathrm{ha}$ and $26 \%$ more than control treatment. Positive correlations $(\mathrm{r}=0.85)$ and $(\mathrm{r}=0.96)$ was observed between calcium and potassium contents in grain and grain yield of rice. However, negative correlation (-0.92) between Na contents in grain and paddy yield was found. It indicated presence of significantly higher $\mathrm{Ca}$ and $\mathrm{K}$ contents in grain receiving wheat straw application combined with $\mathrm{N}$ starter dose. Its application helped plants to attain more $\mathrm{Ca}$ and $\mathrm{K}$ to avoid sodium uptake which has been an added advantage to alleviate salinity/sodicity. Economical analysis showed maximum value cost ratio $(5.45: 1)$ with the application of 5 tons wheat straw/ha along with $90 \mathrm{~kg} \mathrm{~N} / \mathrm{ha}$.
\end{abstract}

Keywords: rice, crop residue incorporation, salt affected soil, N starter dose

\section{Introduction}

Soil salinization is one of the major factors that contribute to land degradation and decrease in crop yield (Anjum et al., 2005; Yassin, 2005). The negative effects of salinization are intensified by the low levels of soil organic matter (Muhammad et al., 2005). Salinity poses threat to crop production in many areas of the world including Pakistan (Ashraf and Foolad, 2007; Hasegawa et al., 2000). It has been estimated that almost 40,000 ha of arable land in Pakistan is being lost due to salinity and the area is rapidly increasing each year (Ashraf et al., 2008; Ahmad et al., 2006). Rice-wheat is the largest cropping system in the world. Approximately $85 \%$ of the rice-wheat area is in the indo-gangatic plains of South Asia covering Nepal, Bangladesh, India and Pakistan (Timsina and Connor, 2001). Rice is highly valued cash crop that earns substantial foreign exchange, grown on an area of 2.96 million hectare with production of 6.952 million tons (GOP, 2009).

*Author for correspondence; E-mail: hyder292002@yahoo.com
However, the farmers cannot afford chemical fertilizers and pesticides to achieve the potential which is much higher than the national average paddy yield. Hence, there is an urgent need to develop a technology which can fulfill crop production and better utilization of crop residue for soil fertility improvement. As per fertilizer off take data, N: P fertilizer use ratio is $4.67: 1$, the balance of fertilizer use is in favour of nitrogenous fertilizers (GOP, 2009). Fertilizer off take data showed $5.9 \%$ decrease in potassic fertilizer use during 2009 as compared to 2008 which is 25.3 thousand tons. As a result of imbalanced fertilizer use, crop productivity is decreasing. Under present situation the combined use of rice or wheat straw and inorganic fertilizer can, however, increase the yield of rice and wheat in ricewheat systems (Mahapatra et al.,1991) Despite some advantages like killing of deleterious pests and clearing the piles before wheat planting, burning results huge losses of $\mathrm{N}$ (up to $80 \%), \mathrm{P}(25 \%), \mathrm{K}(21 \%)$ and S (460\%), air pollution (@ $\mathrm{CO}_{2} 13 \mathrm{t} / \mathrm{ha}$ ) depriving soils of organic matter (SOM). This loss of SOM is one of the 
recognized threats to sustainability. Incorporation leads to build up of SOM, soil N, P and K. The major disadvantage of incorporation is the immobilization of inorganic N. However, N at $15-20 \mathrm{~kg} / \mathrm{ha}$ as starter dose with straw incorporation increases yield of wheat and rice compared to burning (Krishna et al., 2004).

Wheat is the principal crop grown over an area of 9.05 million hectares with 24.032 million tons yield in Pakistan (GOP, 2009). Wheat grain is consumed as major staple food in the country. Approximately 25 million tons wheat straw is produced annually. Major proportion of wheat straw is being consumed by livestock. No doubt wheat straw is being considered more precious than paddy straw. However, considerable area under wheat is being harvested by combined harvester. The combined harvester leaves behind a large amount of loose straw in the field whose disposal or utilization is difficult, time consuming and laborious. So farmers are compelled to burn the crop residues causing major environmental threat whereby application of $\mathrm{N} 15-20 \mathrm{~kg} /$ ha as starter dose with straw incorporation increases yields of wheat and rice compared to burning of straw (RWC-CIMMYT, 2003).

As compared to paddy straw, wheat straw is relatively easier to manage than rice crop residue because time between wheat harvesting and rice transplantation is relatively more than time available between rice harvesting and wheat plantation. Temperature, moisture and microbial population are also more conducive for decomposition of wheat residue and $\mathrm{C}$ : $\mathrm{N}$ ratio of wheat straw is closer than rice residue. $\mathrm{C}: \mathrm{N}$ ratio is an index to visualize how early the material is likely to decompose. The ideal C:N ratio is 20:1. However, wheat straw $\mathrm{C}: \mathrm{N}$ ratio is wider like 40:1. To bring this ratio closer, $\mathrm{N}$ fertilizer is added to boost up decomposition process so that early mineralization of the straw can contribute nutrients for plant growth. Moreover, the availability of $\mathrm{K}$ and $\mathrm{Ca}$ reduces the $\mathrm{Na}$ uptake from solution root interface. Therefore the study has been designed to investigate the viability of incorporating wheat straw along with $\mathrm{N}$ starter dose and its impact on paddy yield and soil health under saline sodic soils.

\section{Materials and Methods}

A field experiment was conducted to determine the effect of crop residue incorporation along with $\mathrm{N}$ starter dose on rice (super basmati) production and soil health at SSRI, Pindi Bhattian, Pakistan under saline sodic soils during Kharif season 2009 (Table 1). Treatments were arranged using randomized complete block design (RCBD) with three replications. The treatments were: Control, 5 tons wheat straw/ha, T2+30 kg N/ha, T2+60 kg N/ha and T2+90 kg N/ha. The wheat straw was incorporated in all treatments except control. The soil was prepared by puddling and a recommended dose of $\mathrm{P}_{2} \mathrm{O}_{5}$ and $\mathrm{K}_{2} \mathrm{O} @ 80$ and 50 $\mathrm{kg} / \mathrm{ha}$, respectively to all treatments. Full dose of $\mathrm{P}$ and $\mathrm{K}$ were applied at the time of rice transplantation. The crop was irrigated with tube well water throughout the growth period. Tubewell water applied during growth of rice crop has high residual sodium carbonate (RSC). However, ECw is marginally higher than salinity threshold value of $1.5 \mathrm{dS} / \mathrm{m}$ (Table 2 ). Necessary plant protection measures were taken whenever required. Data on tillers, plant height, panicle length, number of grain/panicle, 1000 grain weight, straw and paddy yields were recorded at the time of crop harvest. Plant samples were oven dried at $60{ }^{\circ} \mathrm{C}$ to a constant weight and recorded dry matter yield. Grain and straw samples were ground using Wiley mill then digested in perchloricnitric diacid $(2: 11 \mathrm{~N})$ mixture (Rhoades, 1982) to estimate $\mathrm{Na}, \mathrm{K}, \mathrm{Ca}$ and $\mathrm{Mg}$ by atomic absorption spectroscopy. The data thus obtained were analyzed using MSTATC and treatment means were separated using LSD test.

\section{Results and Discussion}

Growth and yield. Salt-affected soils are characterized by high concentrations of soluble salts and low organic matter and nitrogen content (Asma et al., 2009).

Table 1. Physico-chemical analysis of the soil at SSRI Farm, Pindi Bhattian

\begin{tabular}{|c|c|c|}
\hline Parameters & $\begin{array}{l}\text { Value before residue } \\
\text { incorporation }\end{array}$ & $\begin{array}{l}\text { Value after residue } \\
\text { incorporation }\end{array}$ \\
\hline $\mathrm{pH}(1: 1)$ & 8.52 & 8.28 \\
\hline $\mathrm{ECe}(1: 1) \mathrm{dS} / \mathrm{m}$ & 5.32 & 5.74 \\
\hline $\operatorname{SAR}\left(\mathrm{m} \cdot \operatorname{mole}_{\mathrm{c}} / \mathrm{L}\right)^{1 / 2}$ & 18.38 & 17.13 \\
\hline $\mathrm{CaCO}_{3}(\%)$ & 21 & 20 \\
\hline $\mathrm{OM}(\%)$ & 0.8 & 1.02 \\
\hline Sand (\%) & 63 & 63 \\
\hline Silt (\%) & 17 & 17 \\
\hline Clay (\%) & 20 & 20 \\
\hline Textural class - & Sandy loam & Sandy loam \\
\hline Available N (mg/kg) & 6.5 & 9.5 \\
\hline Available P (mg/kg) & 4.3 & 7.1 \\
\hline Available K (mg/kg) & 23 & 32 \\
\hline
\end{tabular}

$\mathrm{SAR}=$ sodium adsorption ratio $; \mathrm{OM}=$ organic matter 
Table 1 indicates that the soil $\mathrm{pH}$ was lowered and SAR decreased due to acidic effect of wheat straw incorporation combined with $\mathrm{N}$ starter dose. It helped acids release of $\mathrm{Ca}$ and leaching of $\mathrm{Na}$. There was a slight increase in ECe of the soil. The available amount of all the major plant nutrients $(\mathrm{N}, \mathrm{P}, \mathrm{K})$ and organic matter content increased in the soil. These results are in consonance to the findings of Sarwar et al. (2008). Data in Table 3 indicates that crop residue incorporation alone and with $\mathrm{N}$ starter dose significantly affected plant height, number of tillers, panicle length, number of grains/panicle, straw and paddy yield. Maximum plant height $(136.66 \mathrm{~cm})$, maximum numbers of tillers (40.33) and maximum panicle length $(28.66 \mathrm{~cm})$ were recorded in treatment receiving straw incorporation @ 5 ton/ha along with $90 \mathrm{~kg} \mathrm{~N} / \mathrm{ha}$. The highest number of grains per panicle (140.33) was recorded in treatment receiving wheat straw incorporation@ 5 ton/ha along with $90 \mathrm{~kg} \mathrm{~N} / \mathrm{ha}$ and the lowest in control treatment. Thousand grain weight is an important index of grain health. Treatments receiving residue incorporation along with 30, 60 and $90 \mathrm{~kg} \mathrm{~N} /$ ha as starter dose produced healthy grain comparing with control treatment just receiving chemical fertilizer at recommended rate. Straw yield (24.46 t/ha) and grain yield (3.32 t/ha) were the highest in treatment receiving 5 tons wheat straw along with $90 \mathrm{~kg} \mathrm{~N} / \mathrm{ha}$ and the lowest paddy yield (2.53 t/ha) was recorded in control. By the comparison of different treatments, it can be concluded that residue incorporation enhanced yield over control to a variable degree. This is the second crop in field receiving residue incorporation along with starter $\mathrm{N}$ dose. With the passage of time, soil fertility is improving as is evident from grain yield and resultantly less fertilizer addition will be needed. Microbial activity would have increased due to residue incorporation and $\mathrm{N}$ addition helping rapid decomposition. $\mathrm{N}$ starter application influence crop residue decomposition, nutrient release, and crop yields (Bijay and Bronson, 2001).

Ionic concentration. Ionic concentration in straw and paddy was found to be statistically significant except $\mathrm{Mg}$ and $\mathrm{Na}$ in straw and paddy (Table 4). Sodium uptake was higher in rice grain in control and the lowest where wheat straw@5 t/haalong with 90 kg N/hawas applied. This showed that crop residue incorporation alone and along with $\mathrm{N}$ as starter dose reduced sodium uptake in rice grains. $\mathrm{Ca}$ and $\mathrm{K}$ uptake by grain was relatively more where wheat straw was applied along with $\mathrm{N}$ starter dose. It can be concluded that incorporation of residue enhanced the availability of $\mathrm{K}$ and $\mathrm{Ca}$ to plant roots. Under saline conditions, plant can better cope with salinity in the presence of calcium and $\mathrm{K}$. The presence of calcium also enhances rehabilitation of sodic soils which is prevalent in rice-wheat growing area. Furthermore with the continuous addition of crop residue, the availability of $\mathrm{K}$ and $\mathrm{Ca}$ is likely to increase. As a result, rate of rehabilitation of sodic soil will take place.

Data in Fig. 1 indicates significant positive correlation $(r=0.85)$ between calcium contents in grain and paddy

Table 2. Water analysis of tubewell

\begin{tabular}{lll}
\hline \hline Parameters & Unit & Value \\
\hline $\mathrm{pH}$ & - & 8.1 \\
$\mathrm{ECe}$ & $\mathrm{dS} / \mathrm{m}$ & 1.7 \\
$\mathrm{RSC}^{*}$ & $\mathrm{meq} / \mathrm{L}$ & 15.2 \\
$\mathrm{HCO}_{3}$ & $\mathrm{meq} / \mathrm{L}$ & 17.5 \\
\hline \hline
\end{tabular}

*residual sodium carbonate

Table 3. Effect of wheat straw incorporation supplemented with $\mathrm{N}$ as starter dose

\begin{tabular}{llllllll}
\hline \hline Treatment & $\begin{array}{l}\text { Plant } \\
\text { height } \\
(\mathrm{cm})\end{array}$ & $\begin{array}{l}\text { No. of } \\
\text { tillers }\end{array}$ & $\begin{array}{l}\text { Panicle } \\
\text { length } \\
(\mathrm{cm})\end{array}$ & $\begin{array}{l}\text { No. of } \\
\text { grain/ } \\
\text { panicle }\end{array}$ & $\begin{array}{l}\text { Straw } \\
\text { yield } \\
(\mathrm{t} / \mathrm{ha})\end{array}$ & $\begin{array}{l}\text { Grain } \\
\text { yield } \\
(\mathrm{t} / \mathrm{ha})\end{array}$ & $\begin{array}{l}1000 \text { grain } \\
\text { weight } \\
(\mathrm{g})\end{array}$ \\
\hline $\mathrm{T} 1=$ Control & $126.00 \mathrm{~b}$ & $28.66 \mathrm{~d}$ & $24.33 \mathrm{c}$ & $88.00 \mathrm{~d}$ & $14.76 \mathrm{e}$ & $2.53 \mathrm{~d}$ & $20.66 \mathrm{bc}$ \\
$\mathrm{T}=$ Straw incorporation & & & & & & & \\
@ 5 tons/ha & $128.66 \mathrm{~b}$ & $32.66 \mathrm{c}$ & $27.66 \mathrm{a}$ & $93.66 \mathrm{c}$ & $16.13 \mathrm{~d}$ & $2.64 \mathrm{~d}$ & $21.66 \mathrm{ab}$ \\
$\mathrm{T} 3=\mathrm{T} 2+30 \mathrm{~kg} \mathrm{~N} / \mathrm{ha}$ & $136.00 \mathrm{a}$ & $38.33 \mathrm{~b}$ & $25.33 \mathrm{bc}$ & $98.66 \mathrm{c}$ & $20.96 \mathrm{c}$ & $2.86 \mathrm{c}$ & $19.33 \mathrm{c}$ \\
$\mathrm{T} 4=\mathrm{T} 2+60 \mathrm{~kg} \mathrm{~N} / \mathrm{ha}$ & $133.00 \mathrm{a}$ & $40.33 \mathrm{a}$ & $26.33 \mathrm{~b}$ & $122.33 \mathrm{~b}$ & $22.23 \mathrm{~b}$ & $3.14 \mathrm{~b}$ & $22.33 \mathrm{a}$ \\
$\mathrm{T} 5=\mathrm{T} 2+90 \mathrm{~kg} \mathrm{~N} / \mathrm{ha}$ & $135.66 \mathrm{a}$ & $40.33 \mathrm{a}$ & $28.66 \mathrm{a}$ & $140.33 \mathrm{a}$ & $24.46 \mathrm{a}$ & $3.32 \mathrm{a}$ & $23.00 \mathrm{a}$ \\
$\mathrm{LSD}$ & 4.294 & 1.031 & 1.031 & 5.168 & 0.1684 & 0.1191 & 1.375 \\
\hline \hline
\end{tabular}

Similar letters do not differ significantly at $(\mathrm{P}<0.05)$ 


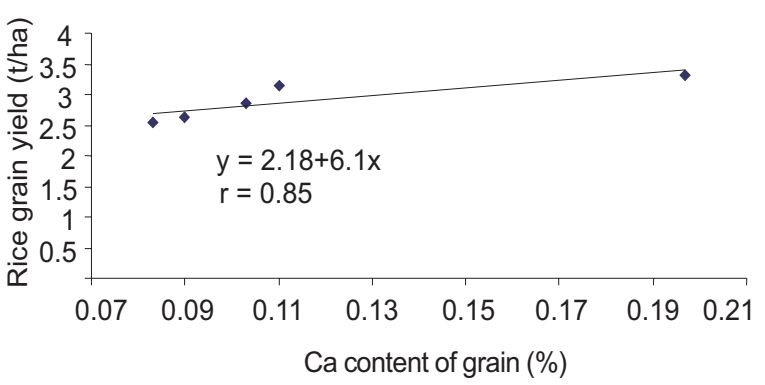

Fig. 1. Correlation Ca content of grain and rice yield. yield. It indicates presence of significantly higher calcium contents in grain receiving residue incorporation combined with $\mathrm{N}$ starter dose. Its application help plants to attain more calcium and $\mathrm{K}$ to avoid sodium uptake which has been an added advantage to alleviate salinity/sodicity using crop residue incorporation apart from enhancing soil fertility and physical properties. Data in Fig. 2 indicates significant negative correlation $(r=-0.92)$ indicating more sodium uptake where calcium and $\mathrm{K}$ uptake was the lowest in control treatment. Data

Table 4. Effect of wheat straw incorporation along with $\mathrm{N}$ as starter dose on $\mathrm{Na}, \mathrm{K}, \mathrm{Ca}$ and $\mathrm{Mg}$ uptake \% by paddy grain and straw

\begin{tabular}{lllllllll}
\hline \hline Treatment & $\begin{array}{l}\mathrm{Ca} \% \\
\text { grain }\end{array}$ & $\begin{array}{l}\mathrm{Na} \% \\
\text { grain }\end{array}$ & $\begin{array}{l}\mathrm{K} \% \\
\text { grain }\end{array}$ & $\begin{array}{l}\mathrm{Mg} \% \\
\text { grain }\end{array}$ & $\begin{array}{l}\mathrm{Ca} \% \\
\text { straw }\end{array}$ & $\begin{array}{l}\mathrm{Na} \% \\
\text { straw }\end{array}$ & $\begin{array}{l}\mathrm{K} \% \\
\text { straw }\end{array}$ & $\begin{array}{l}\mathrm{Mg} \% \\
\text { straw }\end{array}$ \\
\hline $\begin{array}{l}\text { T1=Control } \\
\text { T2= Straw incorporation }\end{array}$ & $0.083 \mathrm{~b}$ & $0.197 \mathrm{a}$ & $0.760 \mathrm{~d}$ & 0.130 & $0.217 \mathrm{bc}$ & $0.320 \mathrm{~d}$ & $1.827 \mathrm{a}$ & $0.637 \mathrm{~d}$ \\
@ 5 tons/ ha & $0.090 \mathrm{~b}$ & $0.163 \mathrm{ab}$ & $0.933 \mathrm{c}$ & 0.130 & $0.327 \mathrm{a}$ & $0.933 \mathrm{a}$ & $1.780 \mathrm{a}$ & $1.057 \mathrm{a}$ \\
$\mathrm{T} 3=\mathrm{T} 2+30 \mathrm{~kg} \mathrm{~N} / \mathrm{ha}$ & $0.103 \mathrm{~b}$ & $0.140 \mathrm{ab}$ & $1.293 \mathrm{~b}$ & 0.123 & $0.323 \mathrm{a}$ & $0.263 \mathrm{~d}$ & $1.627 \mathrm{~b}$ & $0.827 \mathrm{c}$ \\
$\mathrm{T} 4=\mathrm{T} 2+60 \mathrm{~kg} \mathrm{~N} / \mathrm{ha}$ & $0.110 \mathrm{~b}$ & $0.127 \mathrm{~b}$ & $1.337 \mathrm{~b}$ & 0.127 & $0.173 \mathrm{c}$ & $0.590 \mathrm{~b}$ & $1.830 \mathrm{a}$ & $0.683 \mathrm{~d}$ \\
$\mathrm{~T} 5=\mathrm{T} 2+90 \mathrm{~kg} \mathrm{~N} / \mathrm{ha}$ & $0.197 \mathrm{a}$ & $0.123 \mathrm{~b}$ & $1.613 \mathrm{a}$ & 0.117 & $0.260 \mathrm{~b}$ & $0.430 \mathrm{c}$ & $1.057 \mathrm{c}$ & $0.930 \mathrm{~b}$ \\
$\mathrm{LSD}$ & 0.05954 & 0.05954 & 0.05954 & $\mathrm{NS}$ & 0.05954 & 0.05954 & 0.05954 & 0.05954 \\
\hline \hline
\end{tabular}

Similar letters do not differ significantly at $(\mathrm{P}>0.05)$.

Table 5. Economic analysis, partial budget analysis and dominance analysis of crop residue management with $\mathrm{N}$ on rice productivity

\begin{tabular}{|c|c|c|c|c|c|}
\hline & $\begin{array}{l}\text { T1 } \\
\text { Control }\end{array}$ & $\begin{array}{l}\mathrm{T} 2 \\
\text { Straw } \\
\text { incorporation } \\
\text { (a) } 5 \text { tons/ha }\end{array}$ & $\begin{array}{l}\text { T3 } \\
\text { T2 }+30 \mathrm{~kg} \mathrm{~N} / \mathrm{ha}\end{array}$ & $\begin{array}{l}\mathrm{T} 4 \\
\mathrm{~T} 2+60 \mathrm{~kg} \mathrm{~N} / \mathrm{ha}\end{array}$ & $\begin{array}{l}\text { T5 } \\
\text { T2 }+90 \mathrm{~kg} \mathrm{~N} / \mathrm{ha}\end{array}$ \\
\hline \multicolumn{6}{|l|}{ Dose } \\
\hline Input cost Rs. & 0 & 2500 & 3000 & 3500 & 4000 \\
\hline Application cost & 0 & 0 & 0 & 0 & 0 \\
\hline Total cost that vary & 0 & 12,500 & 14,000 & 15,000 & 16,325 \\
\hline Yield grain (kg/ha) & 2530 & 2640 & 2860 & 3140 & 3320 \\
\hline Yield adjusted (10\% Low) & 2277 & 2376 & 2574 & 2826 & 2988 \\
\hline Output price (Rs./kg) & 24 & 24 & 24 & 24 & 24 \\
\hline Yield straw (kg/ha) & 14760 & 16130 & 20960 & 22230 & 24460 \\
\hline Yield adjusted (10\% Low) & 13284 & 14517 & 18864 & 20007 & 22014 \\
\hline Output price (Rs./kg) & 1 & 1 & 1 & 1 & 1 \\
\hline Gross field benefits (Rs.) & 67932 & 71541 & 80640 & 87831 & 93726 \\
\hline Net benefits (Rs.) & 67932 & 69041 & 77640 & 84331 & 89726 \\
\hline \multicolumn{6}{|l|}{ Dominance Analysis } \\
\hline TCV (Total cost that vary) & 0 & 2500 & 3000 & 3500 & 4000 \\
\hline NB (net benefit) & 67932 & 69041 & 77640 & 84331 & 89726 \\
\hline VCR (value cost ratio) & - & 0.44 & 3.24 & 4.68 & 5.45 \\
\hline
\end{tabular}




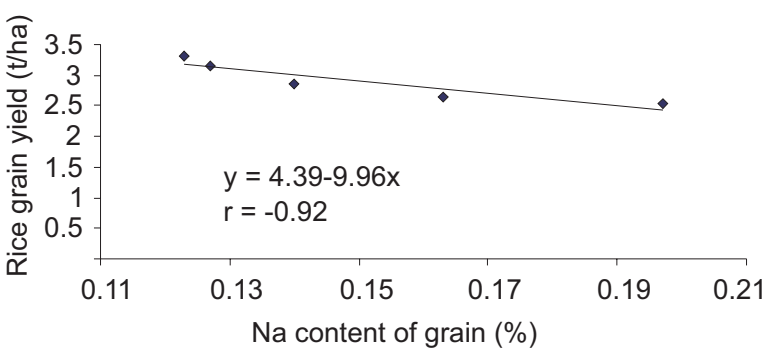

Fig. 2. Correlation between $\mathrm{Na}$ content of grain and rice yield.

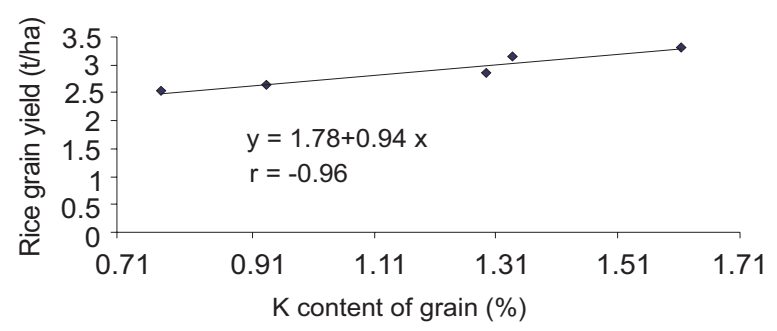

Fig. 3. Correlation between $\mathrm{K}$ content of grain and rice yield.

in Fig. 3 indicates significant positive correlation $(\mathrm{r}=$ 0.96) again indicating more potassium uptake as compared to control treatment. Chemical data indicates that application of residue incorporation along with $\mathrm{N}$ starter combats salinity sodicity by enhanced uptake of calcium and $\mathrm{K}$.

Economic analysis. All the agronomic practices and plant protection measures were same except crop residue incorporation alone and with $\mathrm{N}$ as starter dose. The maximum net benefit was gained when wheat straw incorporation@5 ton/ha along with 90 kg N/ha was applied and that was higher than control treatment (Table 5). Presently N starter dose seems to be necessary for timely decomposition of crop residues. However, with the continuous input of crop residue and enhanced microbial population, starter dose may not be required in future. Dominance analysis is carried out for VCR (Value Cost Ratio) i.e. values of additional crop produce to the additional money spent on straw incorporation and $\mathrm{N}$ fertilizer.

\section{Conclusion}

Paddy yield was the maximum (3.32 t/ha) at the application of 5 tons wheat straw/ha along with $90 \mathrm{~kg}$ $\mathrm{N} /$ ha and $26 \%$ more than control treatment. Residue incorporation along with $\mathrm{N}$ application help plants not only to attain more $\mathrm{Ca}$ and $\mathrm{K}$ to avoid sodium uptake to alleviate salinity/sodicity but also help mineralization and mobilization of essential nutrients to plant apart from adding organic matter, therefore enhancing fertility and productivity of soil through improving the soil physical, chemical and biological properties. N starter dose helps in timely decomposition of wheat straw. Moreover, it is against the iconoclastic practice of burning crop residue and unleashing atmospheric pollution rather it saves the tremendous natural resource a step towards sustainable environmental development.

\section{References}

Ahmad, M.S.A., Ali, Q., Bashir, R., Javed, F., Alvi, A. K. 2006. Time course changes in ionic composition and total soluble carbohydrates in two barley cultivars at seedling stage under salt stress. Pakistan Journal of Botany, 38: 1457-1466.

Anjum, R., Ahmed, A., Rahmatullah, Jahangir, M., Yousif, M. 2005. Effect of soil salinity/sodicity on the growth and yield of different varieties of cotton. International Journal of Agricultural Biology, 4: 606-608.

Ashraf, M., Athar, H.R., Harris, PJ.C., Kwon, T.R. 2008. Some prospective strategies for improving crop salt tolerance. Advances in Agronomy, 97: 45-110.

Ashraf, M., Foolad, M.R. 2007. Role of glycine betaine and praline in improving plant abiotic stress resistance. Environmental and Experimental Botany, 59: 206-216.

Asma, L., Arshad, M., Azam, F., Sajjad, M.H. 2009. Changes in mineral and mineralizable $\mathrm{N}$ of soil incubated at varying salinity, moisture and temperature regimes. Pakistan Journal of Botany, 41: 967-980.

Bijay, S., Bronson, K.F. 2001. Nitrogen-15 balance and use efficiency as affected by rice residue management in a rice-wheat system in northwest India. Nutrient Cycling in Agroecosystem, 59: 227 237.

GOP, 2009. Agricultural Statistics of Pakistan. Ministry of Food, Agriculture and Livestock. Economic Wing. Government of Pakistan, Islamabad, Pakistan.

Hasegawa, P.M., Bressan, R.A., Zhu, J.K., Bohnert, H.J. 2000. Plant cellular and molecular responses to high salinity. Annual Review of Plant Physiology and Plant Molecular Biology, 51: 463-499.

Krishna, G., Mandal, Misra, A.K., Hati, K.M., 
Bandyopadhyay, K.K., Ghosh, P.K., Mohanty, M. 2004. Rice residue- management options and effects on soil properties and crop productivity. Food, Agriculture \& Environment, 2: 224-231.

Mahapatra, B.S., Sharma, G.L., Singh, N. 1991. Integrated management of straw and urea nitrogen in low land rice under a rice- wheat rotation. Journal of Agricultural Science, Cambridge, 116: 217-222.

Muhammad, S., Müller, T., Joergensen, R.G. 2005. Relationships between soil biological and other soil properties in saline and alkaline arable soils from the Pakistani Punjab. In: Microbial Use of Organic Substrates and Maize Growth, Especially in Saline and Alkaline Soils of the Pakistani Punjab. Ph.D. Thesis, pp. 48-71, Department of Soil Biology and Plant Nutrition, Faculty of Organic Agricultural Sciences, University of Kassel, Germany.

Rhoades, J.D. 1982. Cation exchange capacity. In: Methods of Soil Analysis. Part 2. Chemical and
Microbiological Properties, A.L. Page, (ed.), pp. 149-158, American Society of Agronomy, Madison, Wisconsin, USA.

RWC-CIMMYT, 2003. Addressing Resource Conservation Issues in Rice-Wheat Systems of South Asia: A Resource Book. Rice-Wheat Consortium for the Indo-Gangetic Plains-International Maize and Wheat Improvement Centre, New Delhi, India.

Sarwar, G., Schmeisky, H., Hussain, N., Muhammad, S., Ibrahim, M., Safdar, E. 2008. Improvement of soil physical and chemical properties with compost application in rice-wheat cropping system. Pakistan Journal of Botany, 40: 275-282.

Timsina, J., Connor, D.J. 2001. Productivity and management of rice wheat cropping systems: issues and challenges. Field Crops Research, 69: 93-132.

Yassin, A. 2005. Adverse effects of salinity on citrus. International Journal of Agricultural Biology, 4: 668-680. 